\title{
Review
}

\section{How literature changes the way we think}

\author{
Michael Mack \\ Continuum, London and New York, 2012, vii+194 pp., ISBN: 978-1441119148
}

Contemporary Political Theory (2014) 13, e11-e14. doi:10.1057/cpt.2013.36

In How Literature Changes the Way We Think, Michael Mack considers how the humanities and arts can contribute to creative thinking and human resilience. His aim is to sketch out some aspects of 'a new literary theory that combines ethics with aesthetics' (p. 72). Mack aligns his theoretical insights with what he identifies as a 'post-Spinozist' mode of thought, and also brings in insights from and critiques of Walter Benjamin, Paul de Man and Slavoj Žižek, among others. He also endeavors to illustrate his points with examples from both literary texts and popular culture, including treatments of novels such as Kazuo Ishiguro's Never Let Me Go, E.L. Doctorow's World's Fair and the television drama Mad Men, as well as a concluding discussion of Philip Roth. The kernel of his theoretical framework is derived from Hannah Arendt's concept of natality, making this a welcome effort to apply her ideas beyond the realm of political philosophy.

The habit of mind into which people of our age may too easily fall, Mack identifies as 'flat mimesis'. This is a certain mode of representation, or an over-reliance on representation. The notion of mimesis is derived from the Platonic theory of art. The production of an image or an idea as a copy from an original or 'genuine' form is mimesis; and the mimetic nature of art and poetry made it an epistemological problem for Plato. ${ }^{1}$ Mack acknowledges the dependence of the arts and humanities on mimesis, but issues a challenge to 'go beyond the mimetic, while of course not abandoning issues of representation' (p. 17). To Mack, an aesthetics constituted merely by representation has among other downsides the fact that it makes for boring pedagogy: education oriented towards applied skills operates 'within the logic of the copy', while 'the ability to think critically, by contrast, is premised on an analysis of the current state of affairs as well as on reflection upon alternatives that might transform the status quo' (p. 16).

Mack speculates that this 'flat mimesis' describes a problematic condition of our society today. The culture of advertising tends to reinforce social norms and conventions, exemplifying the functions that flat mimesis performs: 'Advertisements present copies of copies, which in turn provoke the mimetic command to copy these series of copies. More importantly, the copying itself promises to offer fulfilment'

(C) 2014 Macmillan Publishers Ltd. 1470-8914 Contemporary Political Theory Vol. 13, 3, e11-e14 www.palgrave-journals.com/cpt/ 
(p. 25). Hence, this attitude avoids confrontation with core issues of human existence, and resists the infusion of imagination or innovation, amounting to the replication of homogeneity. Mack contends that this attitude is likely to be encountered today in both the aesthetic and the social realms.

To this problem of 'flat mimesis', Mack offers Hannah Arendt's theory of natality as the solution. Those acquainted with the phenomenological tradition in philosophy and coming to Arendt's thought from that standpoint may well be surprised by this, since it is more customary to consider Arendt as articulating an alternative formulation to the problem of mortality, or in Heideggerian argot, Being-towardsdeath. $^{2}$ Mack is concerned with existential questions emergent in modern history, particularly the Shoah and the spread of late free-market liberalism. Yet despite this, his analysis falters in its efforts to build a bridge between the literary and the historical, because he does not devote enough space to making the case that the problem of 'flat mimesis' is dispersed beyond the intelligentsia. His in-depth treatments are restricted to artistic or aesthetic works, without a thorough rundown of how to find its symptoms in our society. (This is partly due to the rather disjointed organization of the book as a whole, and partly an effect of Mack's oscillation - in itself no vice - between literary and philosophical considerations.)

The first two chapters frame the critique, including a fascinating yet too brief discussion linking the demand for testing and performance measurement to the attitude of torture. The second chapter notes the importance of Spinoza for getting at these issues, since Spinoza 'attends to distortions within the work of human representations'. In Spinoza we find a philosophy that, contra Cartesianism, insists 'that we unavoidably rely on the life and work of the body, because the "object of the idea which constitutes the human mind is the body"' (p. 29).

Chapter Four on 'Rethinking Suffering' offers a treatment of Nietzschean posthumanism and delivers a critique of Slavoj Žižek, declaring that Žižek's notion of 'fetishism' may be better described as 'flat mimesis'. Here the terminology can become awkward and is insufficiently defined, such as when Mack opposes 'fetishism' to a more fruitful perspectival or 'parallax' viewpoint à la Žižek. Maintaining that 'fetishist' approaches 'cling to one perspective' so much as to confer 'on an ordinary thing the sacred or supernatural status', Mack declares that for the fetishist in the Žižekian sense, the thing is 'consubstantial with the supernatural power it arguably represents' (p. 82), and furthermore this is a flat-mimetic approach.

But some readers will find this critique of religion troubling, for if fetishism involves a misattribution of properties between the mundane and the supernatural or transcendental, then who among actual human beings is not a fetishist? Does Mack mean that absolutely that no fetishism has genuine religious or human value? Or is it that he would bracket literature off from our material existence, at the risk of creating a concept of literature so transcendent as to be unknowable?

Chapters 5 and 6 are the best-developed part of the book, in which Mack articulates the ground for his theory. Some cursory thoughts on Romantic ideas of 
genius and the dynamics of a market system bracket an interesting description in Chapter 5 ('The Birth of Literature') of several important moments in theory over the last century. Walter Benjamin initiated a break with ideas of mimesis and representation (p. 107); this was healthy because it opened literature to extend beyond 'continuous representation of the past and present' (p. 107). Understood in Mack's way, Benjamin makes the philosophy of natality part of aesthetics. While Benjamin's role in the history of aesthetics is indeed fascinating to contemplate, Mack's analyses are more thorough (also more concise) when working in the sphere of literary analysis, such as in the too brief section centered around an engaging example drawn from the legacy of the German romantic poet Hölderlin.

In the sixth chapter, 'The Birth of Politics out of Literature', Mack describes the contrasts between Benjamin and Heidegger. Following this (in Chapter 7) is a discussion of Philip Roth's fiction, in which Mack shows the cogency of the idea of 'the counterlife' depicted in Roth's novel by that title. Roth illustrates the sort of 'defiance of plausibility, coherence, and predictability' that Hannah Arendt appreciated 'as politics in its democratic form' (p. 168). Here Mack begins to draw legibly the connection between Arendt's political theory and the problem of flat mimesis described earlier.

Mack's How Literature Changes the Way We Think comprises interesting, sometimes fascinating inroads toward a diagnosis of the problems of representation, and the effort to describe a theory avoiding these pitfalls seems a helpful project. As a book, however, it falls short of its promise: it does not complete its account of how the desired change in thought happens. For instance, although Mack critiques the Heideggerian approach to the philosophy of literature for practicing a hermeneutics of mimesis - with its insistence that 'by representing the world we interpret it' - he mostly avoids a sustained engagement with Heidegger. This does, however, allow him to work his interpretations of natality out via the methods of literary analysis and theory. Still, a more precise philosophical engagement would be desirable. The material of the book's second half in general would have benefited from a more thoroughly researched and supported treatment, while the organization of the first four chapters and index is hard to follow. The version reviewed here contains an excessive number of typographical and copy-editing errors, and the argument across the whole from chapter to chapter is rather disjointed. To perceive that our theory of representation has led us into a desolate and lifeless territory is not quite enough. Mack leaves us wanting a clearer roadmap to a more vibrant place.

\section{Notes}

1 For an account of the classical view of mimesis, see Kearney (1988, pp. 79-113). Kearney also argues that the Hebrew Bible renders the analogous notion of 'imagination' (yetser) as an ethical problem.

2 On natality, see Arendt (1958, pp. 7-9, 175-181). 


\section{References}

Arendt, H. (1958) The Human Condition. Chicago, IL: University of Chicago Press.

Kearney, R. (1988) The Wake of Imagination. Oxford and New York: Routledge.

Sean Gerard Ferrier Villanova University, Villanova, PA 19085, USA 